\title{
Archaeologia
}

http://journals.cambridge.org/ACH

Additional services for Archaeologia:

Email alerts: Click here

Subscriptions: Click here

Commercial reprints: $\underline{\text { Click here }}$

Terms of use : $\underline{\text { Click here }}$

\section{XII.-On some Accounts of the Royal Wardrobe in the Reigns of Edward I. and Edward II}

Henry Salusbury Milman

Archaeologia / Volume 48 / Issue 02 / January 1885, pp 281 - 284

DOI: 10.1017/S0261340900000874, Published online: 25 January 2012

Link to this article: http://journals.cambridge.org/abstract S0261340900000874

How to cite this article:

Henry Salusbury Milman (1885). XII.-On some Accounts of the Royal Wardrobe in the Reigns of Edward I. and Edward II. Archaeologia, 48, pp 281-284 doi:10.1017/S0261340900000874

Request Permissions : $\underline{\text { Click here }}$ 
XII.-On some Accounts of the Royal Wardrobe in the Reigns of Edward I. and Edward II. By Henry Salusbury Milman, Esq., M.A., Director.

Read January 27, 1881.

Ar the meeting of the Society on this day, the Earl of Ashburnham exhibited the MS. Account of the Keeper of the Royal Wardrobe for 28 Edward T. 12991300, for comparison with that of the Controller of the Royal Wardrobe for the same year, which has long been in the Society's library, and was printed by them in 1787. The volume exhibited is described in the Catalogue of the Ashburnham MSS. Appendix, 1861, No. cxv. In connection with this exhibition the Director made the following remarks :-

"At the above period of history there were always, as I shall presently show, two concurrent Accounts of the Royal Wardrobe, the Keeper's Account and the Controller's Account, but in no instance but this, so far as I know, have both for the same period survived to our time.

The Keeper's Account before us was acquired by the late Earl of Ashburnham, and, through the courtesy of the present Earl, Fellow of our Society, has been left here for several weeks for our perusal.

The Controller's Account for the same year is the earliest of four like volumes which were presented to our Society by the Honourable Daines Barrington from Sir Ashton Lever, Knight, both then Fellows, on the 27th of January, 1780 (Archaeologia, vir. 418), and are numbered 119-122 in our Catalogue of MSS.

This earliest Account now before us was printed in 1787 by our Society as Liber Quotidianus Contrarotulatoris Garderobe, 28 Edward I. It had been mutilated before it came to us. At its beginning the first eight of the ten folios which showed the receipt through the Exchequer, at its end the nineteen folios which showed the Prestitæ, were missing. In printing, the remaining two of the ten receipt folios were purposely omitted, the sum of the receipt through the Fxchequer only being given.

VOL. XLVIII. 
It might seem at first sight that the proper use to be made of the presence of the Ashburnham Account in our library would be, to transcribe therefrom the folios wanting in our Account, and print them as the complement to our print of 1787. On careful consideration I have formed a different opinion. The value of our print consists, not so much in showing with commercial accuracy how every item of receipt and expenditure in the Account for that year arose and contributed to the totals, as in exhibiting the manner of keeping such Accounts, and in illustrating by its details the history, language, art, and manners of the time. 'This is already done. The print has been for nearly a century useful to antiquaries in such researches, and may further be regarded as pointing to the value of like Accounts still remaining in MS. I believe that the printing powers of our Society may be exerted more profitably in other directions, but that I may do a slight service to antiquarian science by explaining how it came to pass that there were two original Accounts of the same transactions kept, and how those Accounts became identical.

It appears from the Dialogus de Scaccario (Madox, History of the Exchequer, 1711 ; Stubbs, Select Charters and other Illustrations of English IIistory, 1870) that hefore the reign of Henry II. there was established in the Exchequer of the kingdom a system of double Accounts, that is to say, a secondary Account contemporary with and checking the primary Account. This secondary Account was kept with minute care, "that its roll might answer to the other roll, that neither one iota might be wanting nor the order of writing be different.' Under this rule, every leaf and page of the secondary answered to a leaf and page of the primary; and so the audit at the end of the year was carried out with ease and accuracy.

The writer of the primary roll was the clerk of the Treasurer ; the writer of the secondary roll was the clerk of the Chancellor. The audit consisted in the Treasurer and Charicellor each with his clerk meeting in conference, and the clerks going over their respective rolls and adding the note ' $\mathrm{pb}^{\mathrm{t}}$ ', probatum, to each item as finally settled. Thus the two rolls became in substance, and almost in form, identical.

It may be noted here, as a matter of curiosity, that the administrative genius of Henry II. provided in this very important office a tertiary Account as a check upon the other two, 'because it is written Funiculus triplex difficile solvitur.'

The two Accounts now before us show that the plan followed in the Exchequer of the Kingdom was also followed in the household or Wardrobe of the King. 
The Custos or Keeper of the Wardrobe kept, by his clerk, the primary Account called the 'Compotus.' Another officer, the Contrarotulator or Controller, kept, by his clerk, the secondary Account called the 'Liber Cotidianus Contrarotulatoris,' or ' Contrarotulus Compoti.' As in the Exchequer, so in the Wardrobe, line almost answered to line, leaf and page quite answered to leaf and page, and the audit was carried out in like manner.

In the Exchequer the two rolls, after audit, were deposited each in its own series apart; but in the Wardrobe they were, after a time, deposited together in the treasury of the Wardrobe. Doubtless this ordinary arrangement was often disturbed by the troubles which fell upon the royal household and rapid changes in its officers ; and hence most of the rolls of both series were dispersed and lost. But for the 28 Edward I. both rolls, as we see, survive. They correspond as required by the rule derived from the Exchequer, leaf to leaf, page to page, almost line to line. The 'probatum,' the mark of audit, has been affixed to the sum of every page, and to the sum of every leaf on its second page, and in some cases, where the sum has been apparently corrected by a second audit, a second mark is affixed to the finally stated sum. The rolls are neither a copy of the other, but separately kept Accounts for the year, brought on the expiration of the year into agreement in the manner described.

In a list of articles remaining in the Royal Wardrobe at the end of 27 Edward I. (see the printed Account, p. 349) are specified eight Wardrobe-Books, two for every year, of four, namely, 15, 16, 17, and 18 Edward I., and divers rolls (some in pockets of hemp) of Wardrobe Accounts of divers years, and of various accounts rendered in the Wardrobe. These entries show the regular course of preserving the two corresponding Accounts of every year together, and the partial disturbance of this regular course.

Of the four Wardrobe-books in our library three are in Latin and the fourth in French.

The three in Latin are Wardrobe Accounts of the 'Controller' series.

No. 119, the eariiest (that printed), is called 'Liber Cotidianus Contrarotulatoris,' 28 Edward I.

No. 120, the second, is called 'Contrarotulus Compoti Custodis,' 10 Edward II.

No. 121, the third, is called 'Liber Cotidianus Contrarotulatoris,' 11 Edward II. 
284. On some Accounts of the Royal Wardrobe in the reigns of Eduard I., \&c.

No. 122, the French book, is not strictly a Wardrobe Account, but rather a collection of notes of money transactions rendered in the Wardrobe in successive years, as materials for the Wardrobe Accounts of those years. It belongs to the Treasurer or Keeper series, and comprises notes for the 18th, 19th, and 20th, the three last years of Ediward II. Many of the entries have been made hastily and informally. In reference to the change of language and looser arrangement, one must bear in mind the growing preference of the King, as his reign proceeded, for foreign officers and attendants, and the confusion of civil war during these latter years. These are probably the very documents which accompanied him in his later marches, voyages, and flights. The last ends in October, 20 Edward II. 1326, about the time when he endeavoured to cross from South Wales to Ireland, was driven back by adverse weather, and finally captured at Neath. Some of the notes of expenses bear the sign of audit or check, ' $\mathrm{pb}^{t}$,' and in two places notice is taken of the commencement of the year in October, 'according to the rule of the Exchequer." " 